\title{
CHARTERING OF OFFSHORE SUPPLY VESSELS IN THE CANADLAN SPHERE - SOME LEGAL IMPLICATIONS
}

\author{
JAMES E. GOULD•
}

\begin{abstract}
This paper contains a considerevian of some conemen provisions of offshore supply vessel cherier parries

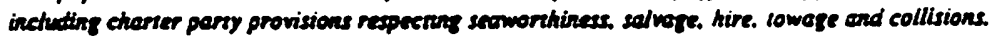

\section{INTRODUCTION}

This paper discusses certain contractual terms which are particulariy maritime in nature and which are commonly contained in charterparties relating to offshore supply vessels and similar craft, as well as the law which bears upon those terms and the charterparty contracts in which they are contained or are incorporated by implication or by reference.

Charterparties, or charters, are simply contracts relating to the use of a ship. and generally fall into two categories: charterparties by demise and those not by demise. The first category relates to those charter agreements where possession of the demised ship is in the charterer rather than the owner. Where a ship is let to a charterer without master or crew, with the master and crew to be supplied by the charterer, the applicable charterparty is generally referred to as a bareboat charter.

The second category of charters includes those situations arising under a contract for the use of a ship where possession and control of the ship are retained by the owner, who agrees with the charterer to render certain services to the charterer with the ship, its master and crew. Such charter agreements are referred to as charterparties not by demise, of which there are two general sub-categories, time charters and voyage charters. Time charters are agreements by the owner to perform defined services with its ship and its master and crew for an agreed period of time, with the remuneration, usually called hire. to be paid by the charterer to the owner at certain periodic intervals. Voyage charters are agreements for the use of the ship, and its master and crew for a particular service or voyage, with the hire or freight being calculated by reference to the quantity of cargo carried or sometimes paid as lump-sum freight for performance of the specified service, rather than by reference to time or duration of service.

The remarks which follow are directed primarily to time charters, for those engaged in offshore oil and gas exploration ordinarily time charter supply vessels from their owners. Although described as "owner" in the time charterparty, the party so described may itself be a bareboat charterer or a preceding time charterer, and there may be a lengthy chain of charterparties between the ship's registered owner and the ultimate charterer.

The vessel itself and its associated equipment are specified in the charter, together with the services to be performed by the ship and its crew. Ordinarily, the owner is obliged to maintain the ship and its associated equipment. although provisions are normally incorporated to permit replacement, repair or substitution of other equipment or capabilities. The owner warrants that the vessel is entered with an accepted Classification Society and agrees to maintain 
the vessel's classification throughout the term of the charter. Other obligations accepted by the owner relate to: the seaworthiness of the vessel at the time of its delivery to the charterer and thereafter throughout the term of the charter; the personnel to be supplied; the keeping, maintenance and inspection of vessel logs; the acquisition of any necessary permits, permissions or licences to carr: out the contemplated work; the maintenance of safety and discipline standards: and compliance with the laws and regulations which apply to the vessel.

The charterer's obligations will, of course, include an obligation to pay hire for the use of the vessel and to pay for fuel, oils, supplies and disbursements used or incurred during the service, and an obligation to redeliver the ship to the owner at the end of the term.

Other clauses are included respecting certain contemplated circumstances which may arise during the term of the charter. Such matters include: the adjustment of rights and obligations among the parties in the event of maritime emergencies, including salvage operations; the termination of the charter; the method of payment of hire; the directions which may properly be given by the charterer; off-hire of the vessel; indemnity clauses; insurance; general average: pollution; liens and charges; the applicable law; and arbitration. This paper will deal with some of these matters which are particularly maritime in nature. As whole books or chapters could be and have been written on each subject. their treatment here must be of a very general nature.

\section{SEAWORTHINESS}

The common law implies, with respect to voyage charters, an absolute warranty of seaworthiness in the absence of contractual provisions which limit or exclude such a warranty. The warranty relates from the time of commencement of the voyage contemplated by the contract.

A good formulation of the absolute warranty of seaworthiness and its application is found in the judgment of Channell, J., in McFadden v. Blue Star Line:'

\footnotetext{
... the wartanty $5 . .$. an absolute wartany. The result shews that in fact there was a defoct. in the sense that the packing wes not as good as it ought to tave been ... Whether a paricular defece is sufficiently subsantial to smount wo brach of the warrany must in all eases be a quenion of fact: but it is a question of fect which must be deterwined by centuin reles. And the rule applicable to the present case is. I think. correctly stated in a pasenge in Carver on Carriage by Sea. s. 18. where it is said that a vesuel -muse have that degree of fitwess which an ordinary careful and prudemt owner would require his vessel to have at the commencenest of bee voyage bavias repard to all the probuble

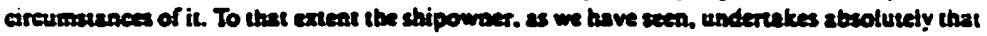
she is fit. and ignorases is no exanse. If the defeet existed. the question to be put is. Would a prudent oweer heve required thas it should be made good before seadias his ship wo sea had he known of it? If he would. the ship was nol seaworthy withia the meaniof of the undernaking:.
}

It is generally accepted that an implied warranty of seaworthiness also applies to a time charter, in which case the warranty must be complied with at the commencement of the period of hiring. 2

1. [1905] I K.8. 697 ax p. 706.

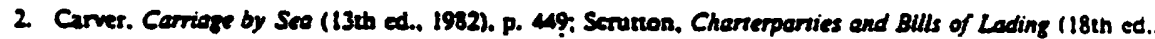
1974). p. 366: Glensean v. Tumbull [1908] S.C. 1101: Hangkong Fip Shippine Led v. Kawasaki Kisen Niasho Ld. TThe "HONGXONG FIR") [1961] 2 Lloyd's Rep. 478 (C.A.): and see generally. Tetley. Manne Cargo Cloums (2nd ed. 1978). Cusprer 13. on seamorthiness and dury to exercise due diligence. 
Ordinarily, express contractual provisions are contained in the charter concerning the owner's obligations with respect to seaworthiness either at the commencement of the service or throughout the term of service. The words "due diligence" are often used in this respect, and there are literally hundreds of cases dealing with the use of those words as they appear in contracts $v i$ affreightment and in various statutes, such as the Carriage of Goods by Hiater Act, ${ }^{3}$ which incorporate the Hague Rules. Where the Hague Rules apply. either by operation of law or by contractual incorporation, the shipowner's absolute warranty of seaworthiness at the commencement of the voyage is replaced by an obligation to exercise due diligence to ensure that the ship is seaworthy before and at the beginning of the voyage. Although the Hague Rules apply to carriage of goods by sea pursuant to a bill of lading, many of the cases decided under the Hague Rules may be of assistance in construing the terms oi $a$ charterparty.

There are some standard forms of time charters for supply vessels, but for the most part, they do not appear to be in common use in Canada. One such form provides that:

\footnotetext{
Owners shall before, at the date of vessed delivery aad throughout the penod of service under this Chancer exercise due diligence to make and maintain the vescel tight. staunch. strong, in good order anc condition, ta every way fit for service. . .
}

and that:

Owners underate that the vescet shall be manned, throughour the period of service under this Charser. by a full and efficiens complement of Master, officens aed crew.

Additional undertakings are incorporated whereby the owner undertakes that the master, officers and crew shall be familiar with offshore operations and practices, and that the vessel will be sufficiently manned to ensure compliance with applicable manning regulations.

Certain Canadian supply vessel charterparties incorporate a clause providing that:

\footnotetext{
The Owner shall. at its sole rist and experse., deliver the vesuel in a seaworthy condition. be prepured to perform the obtigations provided for berein. and exercise due diligence to maintain ther in such a condition and keep her in a thoroughly efficient state including. but not limued to hull. muchinery and equipment. for and during the term of this charter agresment.
}

Another form of charter used in Canada provides, after referring to delivery of the vessel, that:

... she being in cvery way fined for such services insofar as the exercuse of due diligence can make her so and. . . with a mater and full complement of ofticens and erew. Owner shall detiver the vessei in 4 seaworthy condition and in a thoroughty efficient state in hull, muchinery and equspment for the service and shafl exercise due dilizence to maintais and keep her always in such condiuon.

3. RS.C. 1970, c. C-IS; the words "due diligence" appeas in Artide Ill. Rule I of the Schedule to the Act. incorporating the "Hague Rules", so-alled, from the Intemational Convention for the Linification of Cerrain Rutes of Law Retating to Bills of Lading. Signed at 8russels on August 25.1924 - See Singh. Intemeational Conwnnons of Merehent Shippine (20d ed., 1973). p. 1380. The Hague Rutes. or similar but more modern sules. form parn of the domestic lepialation of most maritine countres. 
The first of the two Canadian provisions obliges the owner to deliver the vessel in a seaworthy condition. The reference to due diligence relates only to the maintenance of the vessel's condition thereafter. Therefore, under that clause, the absolute obligation of seaworthiness implied by law applies at the time of delivery for service, and thereafter the owner must exercise due diligence to keep the vessel seaworthy.

The second of the two Canadian examples is slightly ambiguous since it provides that the vessel must be in every way fitted for service upon delivery, insofar as the exercise of due diligence can make her so, but then goes on to provide that the vessel shall be delivered in a seaworthy condition and in a thoroughly efficient state in hull, machinery and equipment, with the obligation thereafter to exercise due diligence to maintain the ship's condition. This clause appears to incorporate the absolute common law obligation to deliver a seaworthy vessel, linked with an obligation to exercise due diligence thereafter to maintain seaworthiness as does the first clause. In the two Canadian charters quoted above, the absolute common law obligation would prevail at the time of delivery of the vessel to the charterer, and the modified obligation to exercise "due diligence" would prevail thereafter.

This gives rise to some interesting possibilities. A ship may be actually unseaworthy in circumstances where the defect is latent or could not have been discoverable by the exercise of due diligence. Unseaworthiness per se is not actionable, and must be a cause of loss or damage before it can be actionable. Many times, unseaworthiness acts in concer with other perils, such as negligence on the part of the master, officers and crew, or perils of the sea (many of which may be "excepted perils" under the terms of the charterparty), but so long as unseaworthiness (or the failure to exercise due diligence) is "a cause" of the loss or damage and assuming the absence of exclusion clauses relating to seaworthiness, the owner will be liable for the loss or damage so caused by or attributed to unseaworthiness. ${ }^{4}$

The legal consequences for the owner if the ship is unseaworthy at the commencement of service or if there is a failure to exercise due diligence when required may not be too onerous. According to Scrutton: 5

\footnotetext{
The underiaking of seawortbiness is neither a 'condition' nor a 'warranty'. The right of the charteres to treat the contract as discharged in coraequence of a breseh of the undertakiag depends on whether the breach goes to the root of the contraca.
}

Where the defect may be remedied, the owner would be liable to the charterer, in the absence of express contractual exclusion, for all loss or damage caused by the unseaworthiness or by the failure to exercise due diligence as the case may be. ${ }^{6}$ In addition, as will be discussed later in this paper, charterparties

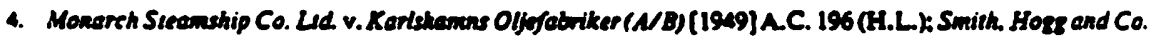

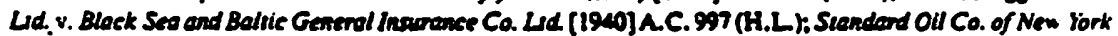
v. Clan Line Sieamers Led [1924] A.C. 100 (H.L); The "CHRISTEL VINNEN" [1924] R. 208: Cenadian Nateonal Railway Co. v. E \& S. Berbour Ld [1963] S.C.R. 323; Heash Steel Mines Led v. The "ERWIN SCHRODER" [1970]Ex. C.R. 426. where it was beld that uaseawortbiness of the ship did not relate to any failure by the owner to exerese due diligence, but rather to the peculiar and dangerous nature of the cargo.

5. Scruton. supran. 2 at 80. See also The "HONGXONG F7R" מpre: The "EUROPA" [1908] R. 84: J. \& E. K!sh v. Chartes Taytor. Sons \& Co. (1912) A.C. 604 (H.L.).

6. Senstion. supro a.2 a 85. 
ordinarily provide that if the vessel is unable to perform due to physical unseaworthiness or lack of efficient manning and equipment, the vessel will go off-hire, and the owner will not be entitled to receive hire payments during that period. The off-hire provisions may impose a deadline for correction of defects, and provide that if the vessel is off-hire by reason of defects for a specified period of time, the charterer shall then have the right to terminate the charter.

Unseaworthiness may relate to factors other than physical inefficiency or inability to meet the rigours of the contracted service. For example, negligeat stowage, failure to follow proper stowage practices, overloading, and inadequate securing of cargo can lead to a finding of unseaworthiness, or a finding that the owner has failed to exercise due diligence in that respect." Incompetence, inexperience or inefficiency of the ship's personnel can lead to similar findings. ${ }^{8}$ Failure to provide adequate instructions to the ship's personnel to accomplish proper operation of the ship and its equipment, even where such personnel are technically competent, may result in the ship being unseaworthy. 9 Inadequate or defective internal piping and other equipment. leaks, out-of-date or inadequate charts, the absence of necessary charts and navigational publications, defective navigational equipment, and a host of other circumstances may render a ship unseaworthy. ${ }^{10}$ The fact that a certificate of seaworthiness or similar document has been issued by a Canadian Steamship Inspector is not sufficient evidence, by itself, to support a finding that the owner has met the burden upon him." "Where the owner shows that it took reasonable and necessary steps to exercise due diligence, the Court is not reluctant to find that the owner has met the burden. ${ }^{12}$

\section{SALVAGE}

The classic definition of a salvage service is set out in Kennedy as being: ${ }^{13}$

A serviee whieh saves or helps ro save a recopoized subjust of salvage when in danger. if the rendenng of suet serviec is voluntary in the sense of being solely attributable neither to pre-exusting. contractual or official duty owed to the owner of the salved propenty nor to the interest of self-preservation.

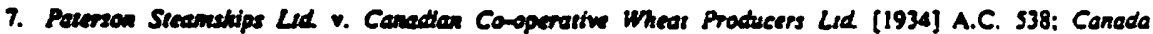
Steanstip Laes Led v. Dessagne (1967) 2 Ex. C.R. 234: Grece Plastics Led. v. The "BERND WESCH IT" et a f1971) E.C. 273.

2. The "MAKEOONIA" [1962] I Lloyd's Rep. 316e Robin Hood Flove Mills Lud. v. N. M. Porersan \& Sons Lid. TT. "FARRANDOC") (1967) I Ex CR. 431; afirmed (1968) I Ex. C.R. 173.

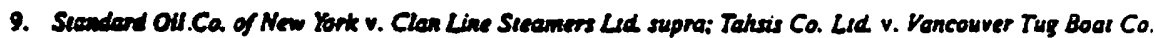
Led [1969] S.C.R. 12: N. M. Patereon \& Sons Lid v. Robin Hood Flow .MIlls Lid. The "BARRA,VDOC", [1960] I Ex C.R. 175.

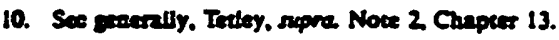

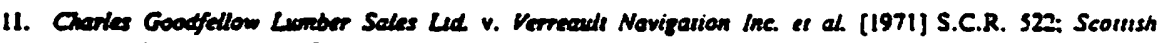

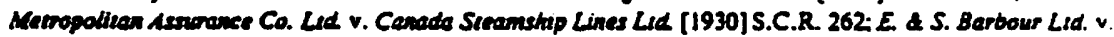
C.N.R (196I) 46 M.RR 331 (NRd. S.C.), afirmed by NRd. C.A. (1962) 37 D.L.R. (2d) 72. and afirmed [1963] S.C.R 323: but ses Normen v. C.N.R. The "WILLAM CARSON") (1982). 39 NRd. \& R.E.I. R. 91 (Nind. C.A.), in which the Cours coneluded that although the ship was unseaworthy at the time of its loss. C.N.R. bad exereiced due diligence by suberiteing to periodic inspections by C.S.I. and in follomng any recommendasioas.

12. Westem Canade Steametip Co. Led v. Canodian Commeneial Corp. et at. [1960] S.C.R. 632.

13. Keneady's Civil Salwge (4tb ed.. 1958). p. S. 
At law, salvage applies only with respect to maritime property, such as a ship, its cargo. freight at risk and related matters. although there are some statutory extentions. Salvage on the high seas is well recognized, and is supplemented by Section 517 of the Canada Shippping Act. ${ }^{14}$ which applies to salvage activities in Canadian waters:

\begin{abstract}
S17. When. within Canadian waters or on or neat the coasts thereor. ans vessel is wrecked. abandoned. stranded or in distress. ano senices are renoered by any person in essisting sush vessel or in saving an! wreek. there shull be payable to the salvor by the owner of such vessel or wreek. as the case may be. a seasonable amount of salvage including expenses properi! incurred.
\end{abstract}

Section 515 of the Act relates to life salvage. and provides that no reward in the nature of salvage for saving of life is payable unless the ship from which the persons are saved, or its cargo or apparel, are also saved, in which case the owner of the salved property is obliged to pay life salvage. So, property must be saved as a condition precedent to a claim for life salvage.

Several other provisions in the Canada Shipping Act relating to salvage may apply to those engaged in offshore oil and gas exploration. Under Section 516 of the Act, the master or person in charge of a vessel is obliged to render assistance to every person found at sea and in danger of being lost, provided that such assistance can be rendered without serious danger to the rescuer's own vessel, its crew or passengers. Such rescue efforts, even though performed under statutory obligation, do not affect the rescuer's right or the right of any other person to claim for or to recover salvage. ${ }^{15}$ Section 445 of the Act obliges the master of any Canadian ship ${ }^{16}$ at sea, upon receiving a signal from any source that a ship or aircraft or survival craft thereof is in distress, to proceed with all speed to the assistance of the persons in distress. The Section further provides that the master of any ship in distress (including a foreign vessel as well as a Canadian ship) may requisition one or more ships as he considers best able to render assistance, and the master of any Canadian ship so requisitioned is obliged to comply with the requisition unless released of the obligation pursuant to Section $445(3)$ and (4). Failure to comply is an offence, ${ }^{17}$ but compliance does not affect the rights of the master of the requisitioned ship or any other person to salvage. ${ }^{18}$ Section 641 of the Canadian Shipping Act obliges the master or person in charge of each ship where two ships collide, to render assistance to and stand by the other, if it can be done without danger.

Finally, Section 514 of the Act extends the statutory and common law relating to wrecks, life and property salvage and duties or obligations to render assistance, to aircraft on or over the sea, tidal waters and Great Lakes, and such law applies to aircraft just as it applies to vesseis. The owner of an aircraft is entitled to a reasonable reward for salvage services rendered by the aircraft, and also may have to pay a salvage reward if the aircraft is saved by another aircraft or ship.

\footnotetext{
14. R.S.C. 1970. c. S-9.

15. Id. s. S16(2).

16. t.e., a ship regustered in Canada under the Canada Shipping ACt.

17. Canada Shippiag Act. s. 44s(5).

18. (1. s. ussiol.
} 
Thus, there are statutory obligations in the Canada Shipping Act which. in certain circumstances, may oblige offshore supply vessels, oil rigs. and support aircraft, to render assistance to ships or persons in distress. oil rigs, and aircraft. Although the rendering of such assistance is compelled in part by statutory obligation, this does not preclude those involved from recovering a salvage award for the services performed.

Rendering of salvage services creates a maritime lien in favour of those who render the service, which lien is enforceable in Courts of competent jurisdiction. including the Federal Court of Canada. In the Canadian context, Part X of the Canada Shipping Act creates exclusive jurisdiction in respect of life or property salvage in either the Federal Court or the Receiver of Wreck. ${ }^{19}$ The Receiver of Wreck has exclusive jurisdiction to hear salvage cases where the claim does not exceed $\$ 100.00$ or the value of the property salved does not exceed $\$ 250.00$, or where the parties agree in writing. ${ }^{20}$ In all other circumstances, exclusive jurisdiction lies with the Admiralty Court, namely the Federal Court of Canada.

It is improper for a salvor to make any attempt to retain possession of the saived property, and such misconduct will ordinarily reduce the award. ${ }^{21}$ In respect of wreck22 which is saved within the limits of Canada, including Canadian waters, the person taking possession of such wreck must detiver it to the Receiver of Wreck, unless delivery is dispensed with by the Minister of Transport. Failure to so deliver without reasonable excuse is an offence and results in forfeiture of any claim for, or right to claim, salvage relating to the wreck, and may subject the salvor to extensive fines in addition to forfeiture. ${ }^{23}$

Generally, a salvor may commence action in the Federal Court of Canada and arrest the salved property 24 to obtain security for the claim. ${ }^{25}$ Although such arrest does not vest possession of the salved property in the salvor, ${ }^{26}$ it does provide a method of obtaining security. The Court cannot order that salved property be released from arrest until there has been a valuation of such property, either by agreement between the parties, or as determined by the Court, or pursuant to a valuation prepared under the Canada Shipping Act. Part X.27

In addition to voluntary salvage services, it is possible for the owners or masters of vessels to enter into agreements respecting the provision of salvage services. Such agreements usually adopt the terms of the well-known Lloyd's Open Form of Salvage Agreement, in which case the security is determined and provided as directed by the Committee of Lloyd's, and the amount of the salvage award is determined by an arbitrator appointed by the Committee of Lloyd's.

19. Pd. \&. 518.

20. Id \& 519 .

21. Heider V. Cowars (1911) 10 EL.R. 61 (N.S.S.C.); The "CHARLES FORBES" (1874) Y.A.D. 172.

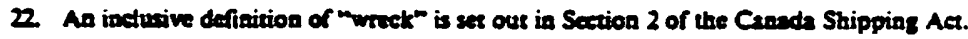

23. Canuda Shippins Act, 3. 500.

24. Federal Coun Acr. R.S.C. 1970 (2nd Supp.) C. 10, as aneended. as. 22(2)(j) and 43(2).

25. Federd Cour Rales, Rule 1003 (arran): and Rule 1005 (bail).

26. Id Rule 10039).

27. Id. Rule 1006(3). 
The parties to an offshore supply vessel charter are generally free to make any contract they wish respecting the provision of salvage services and the treatment of any salvage awards, but other parties may not be bound. or. indeed, may be incapable of being bound, by such arrangements. In the event that an offshore supply vessel becomes engaged in the rendering of a successful salvage service, and in the absence of a binding contract, the owners. maste: and crew of the supply vessel are entitled to advance the claim for salvage. arid the owners of the property salved will be obliged to respond and to provide security for such claims. Ordinarily, and unless otherwise provided by contract, the liability of the owners of the salved property to respond to a salvage claim is several, and not joint, 28 so where a ship. cargo and freight are salved, the salvors will insist upon adequate security from each of the salved interests.

Salvage services may include not only voluntary services. the fulfillment of obligations imposed by the Canada Shipping Act, and services engaged pursuant to contract, but also stand-by services upon request. ${ }^{29}$ in which case the owner, master, officers and crew of the vessel so standing by or providing a requested service are entitled to advance a claim for salvage against the property benefitted. 30

Some offshore supply vessel charters provide that there shall be no salvage award in respect of salving vessels owned or operated by or for the benefit of the charterer, which might include other supply vessels under charter to the oil company or possibly the oil rig being operated by or under contract with the oil company. In most circumstances such a clause would be ineffective to bar any claims by the owners of the salving supply vessel against the owners of the salved rig or supply vessel, ${ }^{31}$ since the owners of the salved property are nor usually parties to the particular charter between the owner and charterer. and since salvage gives rise to a maritime lien and the owners of the property salved must respond to a claim in rem. On the face of its, there is no privity of contract between the owner of the salving vessel and the owners of the property salved. It is possible to envisage a situation where they might be so bound. where, on the proper construction of relevant contracts, the oil company can be seen to be acting as agent or trustee for the owners of the subsequently-salved property in respect of the no-salvage clause in the charterparty, but, to date, the Supreme Court of Canada has not upheld any clause directed to conferring contractual benefits upon a third party to the contract, although the Judicial Committee of the Privy Council has done so in certain circumstances. ${ }^{32}$

23. Penineder Twe a Towing Co. v. The "STEPHANIE" (191S) 22 D.LR. 600 (Ex. Ct.).

39. Sex, for exsmple. Manchester Livers Led v. Jue "SCOTIA TRUDER" [1971] F. C. 14 (F.C.A.).

30. In order to wartan an award, a voluntary galvage service muat genesally be successfully completed by ine salviag vesed. The Cours will. however, reward services which. while not immediately suecessful. are readered at request, sueb as standiag by a stricken veset. Or providing inutual towing services. even where snother ship eveatuatly completes the salvere service - see The "SCOTIA TRADER". supra. Note 29: Gull and Lake Noviganom Co. v. The "WOODFORD" [195S] S.C.R. 829.

31. Different comaiderations might prevail in the undikely situation that the other suppl! vessel or the rig wer: owned by the oil company.

32. See geaerally: Scrutons Ld v. Midlend Silicones LId [1962]A.C. 446: Canedien General Eleciric Co. Lid 、 Pickford \& Bleck Led. The "LAKE BOSOMTWE" [1971] S.C.R. Al: Greenwood Shopping Ple:0 Lid ।

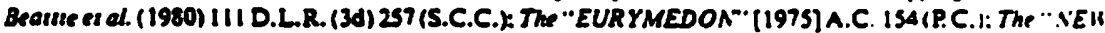

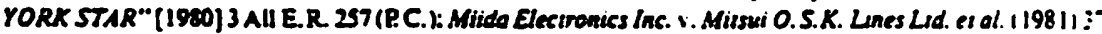
N.R. 396 (F.C.A.). 
Furthermore, the master, officers and crew would not usually be bound by a no-saivage agreement made by their owners, because they are not parties to the charer and could not be bound by its provisions. Although there may be circumstances where the owner of a ship rendering salvage services might be taken to bind the master of the ship not to advance a salvage claim if the owner had the master's authority to do so, the owner cannot bind crew members. The relevant parts of Section 198 of the Canada Shipping Act provide:33

\begin{abstract}
198.(1) A seaman does not by any agreement forfeit his lien on the ship. nor is he deprived of $2 n$ ! remedy for the recovery of this wages. to which in the sbsence of the apreement he would be entuled. and does not by any agreernem abandon his right to wages in case of the loss of the ship. or abandon any right that he may have or obrais in che anture of salvage: and every stupulation in any agreement incosasisent with any provision of this Act is void.

(2) Nothing in this sectios applies to a rapulation mede by the seamen betonging to any ship that. secording to the terms of the apresenent. is to be errployed on salvage service. with respect to the resuunerstion to be paid to them for alvape setviess to be rendered by that ship to any other ship.
\end{abstract}

By definition, the term "seaman" includes every person except masters, pilots and apprentices employed or engaged in any capacity on board any ship..$^{34}$ The only exception regarding seamen arises where their ships are employed on salvage service, and where the crew members are on "salvage articies". 35 This exception is intended to apply to salvage tugs used by professional salvors. Crews of offshore supply vessels are not engaged on salvage articles. and cannot legally waive their right to salvage remuneration.

"No-salvage" clauses should be discouraged as a matter of policy. Not oniy are they fraught with legal difficulties as to their enforceability, as discussed above, but also they run counter to the very policy which underlies rewarding of salvage services, namely, to promote and encourage safety and preservation of life and property at-sea. Incorporation of such clauses could only discourage the sometimes superhuman efforts which people will make in the course of a maritime emergency, and might ultimately operate to the disadvantage of those who seek to rely on "no-salvage" clauses, by eliminating the only incentive which such people might have to rescue assets which are of benefit to the charterer.

Another class of vessels deserves some consideration, namely, government ships employed in the service of the Coast Guard or Armed Forces. Such vessels are frequently nearby when offshore emergencies occur, and will often be involved in the provision of services in the nature of salvage. Section 531 of the Canada Shipping Act, and Section 223 of the National Defence Act. ${ }^{36}$ relate to salvage by ships belonging to Her Majesty. The former section, as modified by the latter, applies to ships of war and other unregistered vessels held by or on behalf of Her Majesty in right of any Commonwealth country, except vessels used in the Canadian Forces, and the latter section relates to those ships used in the Canadian Forces. Claims for salvage services rendered by the former class of vessels may be brought by the commander and crew, but may not be finally adjudicated upon uniess the consent of the Governor-in-

\footnotetext{
33. Sce also The "LEON BLUM" [191S] R. 90: . Kenchester Liners Lid, v. The "SCOTJA TRADER". supre n.:9

34. Canede Shuppris Aet. s. 2

35. 14. 3. 19212.

36. R.S.C. 1970. C. NA
} 
Council to the prosecution of the claim is proved. The consent of the Minister of National Defence must be proved before a salvage claim of a commander and crew of a ship in the Canadian Forces can be determined. Her Majesty is free to claim salvage in either case, and the consent provisions do not apply with respect to registered government vessels such as Coast Guard ships and icebreakers. ${ }^{37}$

Most offshore supply vessel chareers provide for the division of salvage monies earned by the vessel. It is most usually agreed that the net salvage proceeds will be divided equally between the owner and the charterer, after deduction of the master's, officers' and crew's share of salvage, legal expenses. hire of the vessel during time lost, value of fuel consumed in the course of the service, cost of repairs of any damage incurred by the vessel in the course of the service, and related expenses. The provision appears to be a sensible one, in that it recognizes the commitment of both parties to performance under the charter and it recognizes to some extent their respective risks in the event of the rendering of a salvage service. In addition, it provides for the adjustment of awards and expenses between the two parties, and permits and encourages the masters, officers and crews to engage in salvage activities, since the award due to them will not be reduced or affected by the arrangements between the owner and the charterer.

\section{TOWAGE}

One of the usual obligations of an offshore supply vessel is to perform certain specified towage services. In the absence of contractual provisions relating to the terms under which such towage will be performed, the common law will apply. ${ }^{38}$ Skilled draftsmen have devised certain standard towing conditions which are often incorporated by reference in charters of offshore supply vessels.

To appreciate the significance of the draftsmen's art, it is useful to examine the duties imposed at common law upon the tug owner under a contract of towage. There are several implied terms which apply to such agreements at common law, namely:

1. Except in the case of the engagement of a "named tug", the tug must be sufficient as regards seaworthiness, equipment, power and manpower, at the commencement of the towage service, to perform the service which she undertakes in the weather and other circumstances reasonably to be expected in the course of the tow. ${ }^{39}$ The obligation is akin to a warranty of fitness for purpose, although it has been beld that the obligation does not amount to an absolute warranty such as the implied warranty of seaworthiness. ${ }^{40}$ The obligation does not apply if the tug engaged is a "named tug"."41

37. "Shups betongine to Her Majasty" are defined in Canada Shipping Act, s. 2

38. The "WEST COCK" [1911]P. 23, and 208 (C.A.).

39 The "MARECHALSLCHET' [1911]P. 1: The Tug "CHAMPLAIN" v. Canada Sieomship Lines Lid. [1939] EX. C.R. 89: The "LNDAUNTED" (1B86) II R.D. 46: The "WEST COCK". sepre n. 38.

to. The "WEST COCX" (C.A.). supro n. 38.

11. The TuR "CHAMPLAS" v. Canoda Sieamship Lines Lid. supre. n. 39: Robernson v. The Ameson Tur and Lighieroge Co. (1881) ? Q.B.D. 598 (C.A.): Pointe Anre Quomes Led v. The "M. E. WHALE.A" (1923) I D L.R. AS (P.C.). affirming 63 S.C.R. 109. 
2. In the performance of the tow, reasonable and proper competence. skill and diligence shall be exercised. 42

3. Proper skill and diligence shall be exercised on board both the rug and the tow, and neither vessel will, by neglect or misconduct, create unnecessary risk to the other or increase any risk which might be incidental to the service undertaken. ${ }^{43}$

Most Canadian offshore supply vessel charters, if they incorporate any standard towing conditions at all, will incorporate the United Kingciom Standard Conditions for Towage and Other Services (Revised 1974), a copy oi which is attached as Appendix " $A$ " to this paper. A copy of the Conditions is rarely attached to the charter, and the conditions are usually incorporated by reference only. The Eastern Canadian Tug Owners' Limited Standard Conditions are set out in Appendix " $B$ " to this paper. The U. K. Conditions will be considered here, because they are more current.

Ordinarily, to be protected by the towage contract, actual "towing" must have commenced. The U. K. Conditions define "whilst towing" in Clause l(b)(iv), and the term "whilst towing" has been held to apply when those on board the tug may reasonably expect the tow to give the tug an order to pick up ropes or lines, at which time the tug must be ready to respond to such an order. and at which time the tug must be within hailing distance. 44

In the context of offshore operations, Clause 4 of the U. K. Conditions is noteworthy, because it seeks to absolve the tug owner from virtually all conceivable responsibility for damage done by or to the tug, by or to the tow, to any cargo which is on board, or to any cargo which is being loaded or which is intended to be loaded on board either the tug or the tow, or for loss of the tug or tow or any cargo, or for personal injury or loss of life, or for third party claims arising from any cause, including negligence of the tug owner's servants or agents at any time, or for unseaworthiness, unfitness, breakdown, failure of towing gear or equipment or lines, lack of fuel, and so on. The clause furthermore obliges the tow owner to indemnify the tug owner with respect to any of the matters or casualties identified in the clause, except where the tow owner can establish that the damage or loss was caused solely by the failure of the tug owner and was due to the actual fault or privity of the tug owner to make the tug seaworthy for the towage service. ${ }^{45}$

In The APOLLON, 40 for example, the vessel was waiting to enter a dock, and her master signed a towage order for two tugs, one of which had been made fast and had commenced towing, while the other was abreast of the APOLLON's bridge, being not yet made fast, and awaiting orders. The pilot asked the second tug to take a line aft and act as a stern tug. While this second tug was

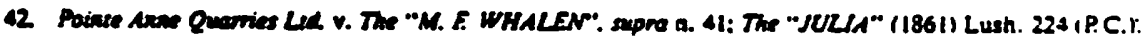

43. The "SUULA". supra a. 42: Spaight v. Tedcassle (1881) 6 App. Cas. 217 (H.L.): .McCormick v. Suncennes.

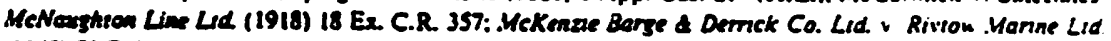
(1960) 70 D.L.R. (2d) 409 (Ex. Ct.L.

44. Anisish Tranqon Dacks Boand v. Apollon (Owaen) TThe "APOLLON") (1971) I Lloyd's Rep. A:6: The "URANIENOORG" (1936) R 21: "BLENHEIAN" (Owners) v. "IMPETL'S" (Owners) iThe "I.HPETL'S") [1959] \& 111.

45. "Actual faut or privity" means personal faut on the part of the cug owrer. not veanous responsibilitv Some comments on "ectud fault of privity" follow in the part of this paper dealing with "Limitation of Linbility".

46. Supra n. 4a. 
maneuvering to come up astern of the APOLION, the tug struck a moored lock gate and sustained propeller damage. The tug owners claimed indemnity in respect of such damage pursuant to the relevant $U$. $K$. Conditions. Although the tug was not physically towing, the Court concluded that the prescribed tests were met, and that the owner of the tow was obliged to indemnify the tug owner for the damage to the tug.

The significance of incorporating the U. K. Conditions, particularly Clause 4 , in a Canadian offshore supply vessel charter is that it effects an entirely different allocation of responsibilities than that which would normally arise or be predicted to arise under the charter or by law. If the U. K. Conditions apply, they may give rise to responsibilities and liabilities not contemplated at all in the agreement of the ordinary provisions and conditions of a charter. For example, it would appear that Clause 4, if applicable, will govern responsibility for all mishaps occurring whilst towing, and that the indemnity would be enforceable even in the case of fundamental breach. 47 These circumstances alone provide ample reason for owners and charterers alike to ensure that underwriters have been fully advised of the terms of the charter, so that potential liabilities and losses are contemplated, understood and covered by insurance.

Some offshore supply vessel charters, while incorporating the U. K. Conditions, expressly limit their application to certain specified situations, such as iceberg towing. In this connection, it should be noted that the 1974 U. K. Conditions define "vessel" as including "any vessel, craft or object of whatsoever nature (whether or not coming within the usual meaning of the word "vessel')". Thus, as defined in the Conditions, "vessel" may include not only icebergs, but various other things which might not ordinarily be considered "ships or vessels" within the judicially-defined or statutory meanings of those words. 48

One further point should be addressed. There are circumstances in which a towage service may become a salvage service. Such services cannot co-exist, 49 but there are situations in which it may be argued that, due to circumstances, a salvage service was rendered rather than a towage service, and that compensation should be paid on a salvage service basis. Ordinarily, this would arise where a vessel or other object has been taken in tow with no prior agreement, or where a vessel was being towed pursuant to a towage contract but circumstances changed following the commencement of the tow to a degree sufficient to warrant a change in the nature of the service.

In the absence of a towage agreement, Canadian Courts will rely upon the descriptions of towage services made by Dr. Lushington in The REWARDso and The PRINCESS ALICE. ${ }^{51}$ In the first case, Dr. Lushington opined that towage should be confined to vessels that have received no injury or damage, and that a mere towage reward is payable in those cases only where the vessel

47. Phoio Produesion LA v. Securicor Trenspors Ld. [1980] A.C. 827 (H.L.); The "NEW YORK STAR". supra: Beaufort Realines (196) Iac. v. Chomedey Ahuminum Co. LA. (1980) 116 D.LR. (3d) 193 (S.C.C.).

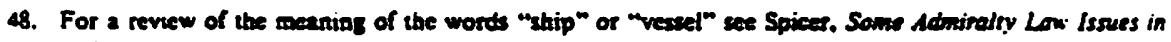
Offshore Oil and Ges Demelopment (1982), 20 Alu. Law Rev. 153.

49. The "LEON BLUM". appe.

So. (1841). I W. Rob. 174 .

si. (1849). 3 W. Rob. 138. 
receiving the service is in the same condition she would ordinarily be in without having encountered any damage or accident. In the second case, he stated that a towage service may be described as the employment of one vessel to expedite the voyage of another when nothing more is required than the acceleration of her progress.

Such principles have been applied by Canadian Courts in wrestling with the distinction between towage and salvage services. 52 Situations in which there is no prior agreement are relatively simple, but complicated problems arise where a towage agreement exists and towage has commenced, but during its fulfillment circumstances change to a degree sufficient to warrant a claim for salvage. Perhaps the best statement on point appears in Kennedy:53

\begin{abstract}
... If during the towage, mithout any fauls on the pan of the tuk. by some cause which the eontracting parties could nor have foreseen. the tow is placed is a possuon of danger, and the rugstands by her. as it is the tug's duty to do. and brings her into safety. either at the place of destination. or, if that is imposeible. at asotber plece, by iacurring risks, of by performing duties, although without risk to berself. whieh could sol sasonsbly be held to be within the seope of the original bargain - the towage coetrest, in such a cast. does not bar the right to additional remuseration, but, to use a common exprestion. is superseded by the right to salvage.
\end{abstract}

\title{
V. COLLISIONS
}

An in-depth analysis of collision and collision liabilities is far beyond the scope of this paper. Nevertheless, offshore supply vessels can and do become involved in collisions, with the rigs they service, with other supply vessels, or with other ships unconnected with the enterprise in which they are engaged. Although the comments on collision must be restricted, the need for comment stems from the almost universal practice of incorporating so-called "both-toblame collision clauses" into charters of offshore supply vessels operating out of Canada.

It is not intended to indulge in the complexities of the adjustment of liabilities in all situations of collision at sea, but it is important to note that Section 638 of the Canada Shipping Act provides: ${ }^{4}$

638.(1) Where, by the frult of two of more vessels. damage of loss us caused to one or more of those vessets. to cheir carsoes of fretght. or to any property on board. the liability to make good the damage or loss shall be in proportion to the degree in which each vesset was in fauth.

(2) Where. having regard to all the circumstances of the case. It is not possible to establish different detres of fautl. the liabtity shall be apportioned equally.

(3) Nothing in this seetion operates to render any vessel liable for any loss or damage to which its fault has not contributed.

(4) Nothing in this section affects the liability of any person under a contract of earnage or any contraet. or shall be construed as umposung any liability upon any person from which he is exempted by any contraet or by any provision of law. or as alfeeting the nght of any person to limut his liability in the manner provided oy law.

(S) For the purpose of this Act. the expression 'frenght' includes passare money and hire. and reference to damage or loss caused by the fauls of a vessel shall be construed as including references to any salvage or other expenses. consequent upon that faute. recoverable at law by way of damages.

52 The "HILLCROFT" (1927) I2 NAd. L.R. 45: The S.S. "KART" v. The S.S. "FER.VFIELD" (1939) I4.Nind." L.R. 263.

53. Supre ก. 13 at 53.

Sa. Supre n. is. 
For example, if an offshore supply vessel carrying cargo owned by the charterer was in collision with an unladen vessel (called "the non-cartying vessel"), and the supply vesset was 75 percent at fault and the non-carrying vessel was 25 percent at fault, the effect of the above provisions of the Canada Shipping Act is that the charterer, as owner of the cargo on the supply vessel, would be entitled to recover 25 percent of its loss respecting its cargo from the owners of the non-carrying vessel. The owners of the non-carrving vessel would not be entitled to recover anything by way of indemnity from the owners of the supply vessel for the liability incurred in respect of the cargo on the supply vessel.

The result is quite different under the laws of the United States. ${ }^{55}$ There, in a both-to-blame collision situation, the cargo owner may recover the whole of its loss, rather than just a proportionate amount, from the owner of the noncarrying vessel, which owner can then add that liability to its own loss, in the division of liabilities with the owner of the carrying vessel. A curious situation then prevails, for if the owner of the carrying vessel was 100 percent to blame, the owner of cargo on that ship could recover nothing from the owner of the non-carrying vessel (and nothing from the owner of the carrying vessel, whose liability ordinarily would be excluded by the terms of the contract of carriage), and thus the owner of the carrying vessel would not be required to make any contribution with respect to cargo; whereas, if the carrying vessel was only 50 percent to blame, it must contribute through the adjustment mechanism an equal amount to 50 percent of the cargo loss paid by the owner of the non-carrying vessel. Hence, in terms of liability for cargo, the owners of the carrying vessel are in a better position if their ship is wholly to blame. The both-to-blame collision clauses came into existence as an attempt by shipowners to rectify the anomaly created by the laws of the United States.

A form of both-to-blame collision clause which is typical of those found in many offshore supply vessel charters reads as follows:

\begin{abstract}
Bob-10-Blame Collision
If liability for any collision in which the Vessel is unvolved while performing this Charter Agreement faits to be desermuned is aceordance with the laws governing this Agreernent as provided herem. the followins provision shall apply:

(a) If the Vesset collides with anotber ship as a result of the other ship's neglegence and any act. neglect or defaull of the Marter. merriber. pilos or servants of the Owner in the navigation of manacements of the Vesud. the Charterer shall indeanify the Oweer againat all loss or liability to the osher or non-carmng ship of ber owness insolas as such loss of lisbility perains to any clatm whatsoever of the Owner for loss of or damage to any goods earried under this Charee Agreement paid or payable by the other or nea-earryias ship or her owness to the owners of said goods and set off or reeovered by the other or noo-arrying stup or her owners as part of their elaum apainst the Veasel of the Owriess.
\end{abstract}

(b) The forcyoung provition shall atso apply where the owners. operators of those in charge of the shup or abjeat ofter than of in tddition to the colliding ships or objects art at fault.

Such a clause is of no effect whatsoever if adjustment of liabilities in a both-to-blame collision situation is determined by a Canadian Court, under Canadian law, since the desired effect is already accomplished by application of Section 638 of the Canada Shipping Act, quoted above. However, incorporation of the clause may be useful in the event that a United States

55. Sex generally. Carver. supre a. 2 at para. 2095. 
Court acquires jurisdiction to adjudicate the liabilities arising out of a collision between ships.

\section{LIMITATION OF LIABILITY}

The liabilities or remedies of owners and charterers of offshore supply vessels may be dramatically affected by the limitations of liability referred to in Part XIV of the Canada Shipping Act. ${ }^{56}$ Section 647 of the Act provides that the owner of any ship where certain events occur without his "actual fault or privity", is not liable for damages beyond 3,100 gold francs per ton in respect of loss of life or personal injury (alone or together with any damage to property or infringement of rights), or beyond 1,000 gold francs per ton in respect of any loss or damage to property or any infringement of rights. The Section specifies the events in which limitation of liability may apply, and stipulates that such limitation of liability applies in respect of each distinct occasion that such events occur. ${ }^{37}$ Entitlement to limitation is not automatic. The burden rests upon the shipowner to establish that the events giving rise to liability occurred without his fault or privity, and, in this country at least, that is a difficult and almost impossible onus to discharge.

The limitation provisions apply not only to the owner of the ship, but also to the charterer, those having an interest in possession of the ship, and to the manager or operator of the ship, where the events giving rise to liability are covered by Section 647 and occur without their actual fault or privity. When such other party seeks entitlement to limitation of liability, the burden of proof rests with him. A master or a crew member or any servant of the owner or of the charterer is entitled in any event to the benefits of limitation, and need not meet any burden of establishing absence of his actual fault or privity. ${ }^{58}$

The principal disputes in cases of limitation of liability relate to the issue of actual fault or privity on the part of the owner. The nature and extent of the onus on the party seeking entitlement to limitation of liability has been discussed in numerous cases. 59 The words "actual fault or privity" have been held to mean something personal to and blameworthy in the owner, as distinguished from his constructive fault or privity arising from the rule of respondeat superior. With respect to a corporate owner, the fault or privity must be that of a person who is more than a servant or agent for whose acts the company would be liable ordinarily on the basis of respondeat superior: rather, the person must be one for whose acts or omissions the company is liable because his acts are the very acts of the company itself. 60

Procedurally, an owner or other person seeking limitation of liability may initiate a Court action seeking a declaration of his entitlement to limitation. He

S6. Supron. is.

57. Cranda Shippins Acr. rupre n. 14 s. 647(J).

S2. Id a 6A9, but were a master as also owner, he will sot be entitled to limitatuon of his liability if he was at

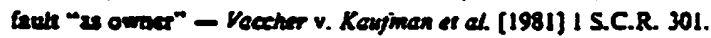

99. See for example: Sreen Espase v. The "KATHY K" [1976] 2 S.C.R. 802: The ".VORMAN" [1960] I Lloyd"s Rep. I (H.L.): Copporation of the Royal Exchenge Assurance v. Kingstey Namgation Co. Led. [1923] A.C. 23S (RC.).

60. Sex for example: Lenpard's Cerrying Co. Lud. v. Astoric Perroleum Co. Lrd. (191S) A.C. 70S (H.L.): Robin Hood MUlis LAd v. Pacerson Sreamships Lid (1937) 3 D.L.R. I (R.C.): Brirshh Columbie Telephone Co. et at. v. Nepole Towing Lid. [1971] S.C.R. 321. 
must then meet the onus of establishing that the events giving rise to liability occurred without his actual fault or privity. Ordinarily, a limitation action of this sort will be brought by an owner where liability is admitted but where there are various classes or numbers of actual or potential claimants whose claims arise out of the same occurrence, and whose claims individually or in aggregate exceed the vessel's limitation fund. Where there is a single claimant whose claim may exhaust the limitation fund, or where the owner of the ship does not admit liability and will be pleading limitation in the alternative to liability, the usual course is to await commencement of the claimant's action, and to invoke the provisions of the Canada Shipping Act by way of Defence and Counterclaim. 61

The benefits or results of limitation can be very significant. For example, for a supply vessel with a limitation tonnage of 1,500 tons, liability for property damage, if limitation applies, would be limited to about $\$ 150,000$, even if damage amounting to millions of dollars occurred. Where loss of life or personal injury is involved, the maximum liability would be about $\$ 465,000$.

The tonnage of a vessel for limitation purposes is the ship's register tonnage plus any engine room space which had been deducted when determining register tonnage. The relevant tonnage figures necessary for such caiculation appear on the vessel's Certificate of Registry. Calculation of the value of the 1,000 or 3,100 gold franes, as the case may be, is governed by Regulations, ${ }^{62}$ pursuant to which gold francs are first converted to Special Drawing Rights against the International Monetary Fund, and then the Special Drawing Rights are converted to Canadian dollars at an exchange rate which can vary from day to day.

\section{GENERAL AVERAGE}

General average is another subject purely maritime in nature which is ordinarily referred to in charterparties. A typical clause might say:

Geveral Average stall be adjusted in Halifax and payable according to the York-Antwerp Rules 1974.

General average must be contrasted with particular average, a situation in which the loss falls wholly on the owner of the particular property damaged or lost. General average arises where a ship and its cargo or freight are exposed to common danger, and the ship, or the cargo, or some portion of each, is deliberately sacrificed, or where some extraordinary expenditure required for the common good is incurred by one of the parties to avoid or minimize the consequences of a common peril to a maritime adventure. ${ }^{63}$

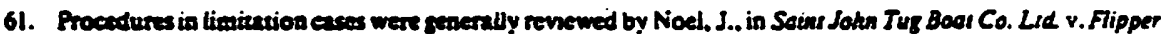
Drogerers Led ef al [1969] I Ex. C.R. 392 See also Nisshin Kisen Kaishe Ld. v. C.A.R. The "JAPAA ERICA") (1981) 122 D.L.R. (3d) S99 (F.C.A.) - before a decterauon of entitiement to timitation ean be given. the owaer must uneonditiosally admit tiability, and where any admistion is conditionah aetions to determine livbility will not be staved.

62. Canada Shippins Aet Gold Franc Conversion Regulations. SOR/78-73; As the S.D.R./Canadian Dollar exchasge nate flueturter. 30 does the value of the timitation fund. which will depend upon the conversion rase appliable at the time of the onder for limitation. of if payment into Court is made, on the conversion rate applieable at the time of payonen in. uatess the payment is insufitecent. in whicb ease the rase on the later date witl apply - Caseda Stuppias Act. s. 651: The "ABADESA" [1968] I Loyd's Rep. 493: The "MECCA" [1968] 2 Lloyd's Rep. 17.

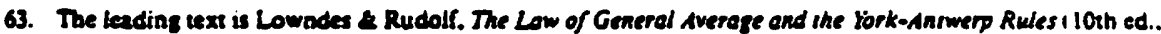
1975). 
General average is perhaps the most ancient legal principle found in our common law. It represents an early manifestation of the concept of commercial socialism and the common good in matters maritime. The principles originated in the Rhodian law thousands of years ago, and the earliest written origins may be found in Greek legislation and are referred to in the Digest of Justinian: ${ }^{6}$

"The Rhodian law decrees thas if in order to lighten ship merehandise has been thrown overboard. that which has been given for all should be replaced by the contnbution oi all."

Definitions of the terms "general average loss" and "general average act" are set out in the Marine Insurance Act, 1906 (U. K.), as follows:65

66.(I) A general average loss is a loss caused by or direetly consequential on a general average act. II includes a gentral average expenditure as well as a general average sacrifiec.

(2) There is a seneral average act where any extraordinary sacrifice or expenditure is voluntarily and ressonably made or incurred in time of peril for the purpose of preserving the property imperilled in the corrmen adventure.

Although the definitions were drafted for insurance purposes, they are regarded as definitions of general application. ${ }^{66}$

Simply put, if some part of the ship or cargo must be sacrificed to save the common adventure, then the cost of making good the sacrifice should be borne by the ship, cargo, and hire which are thus saved, rateably in proportion to the respective interests of each. The concept also applies to port of refuge expenses and similar expenditures which are general average in nature, and which are incurred for the preservation of the maritime adventure.

Some overriding principles applicable to general average are summarized as follows:

(a) General average is applicable only to maritime adventures. ${ }^{67}$

(b) The general average act must relate to a sacrifice or expenditure made or incurred upon an extraordinary, as opposed to ordinary or contemplated, occasion. 68

(c) An actual peril is necessary, and a sacrifice made in the mistaken, although reasonable, belief of a common peril is ordinarily outside general average. ${ }^{69}$

(d) While such peril must be real and not imagined, it need not be immediate. Thus it is not necessary for the ship itself to be in the absolute grip of disaster before an act of general average may validly occur. The reasons for this are based in public policy. ${ }^{70}$ Masters should be encouraged to err on the side of caution, rather than jeopardize the whole adventure, including the possible loss of the ship, her cargo and the crew.

(e) Fear of loss of life alone is in theory insufficient, although Courts may
4. Lowndes \& Rudolf, id at 3.

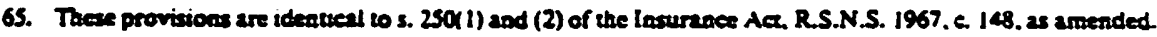
66. Austin Frtors Sironstip Ca. Lid v. Spillers \& Baters Lad [191S] I R.B. 833.
67. Momien Srewnskip Ca. LAd v. "GREYSTOKE CASTLE" (Cargo Owners] [1947] A.C. 265. at p. 310.
68. Soctoce Nownelle of Armesment v. Spillers \& Bekers Led [1917] I K.B. 865.
69. Jaseph Warson and Son Led v. Firemaris Fund Insumerce Co. of San Froirezseo [1922] 2 K.B. 355.
70. Vlassopoudas v. Bnnsh and Forergn .Menme Insurance Co. The "MAKIS") (1929) I K.B. 187 
impute to the master in such situations a fear of loss or damage to the cargo even though he may never have given it a thought. Again, the reasons are based in public policy."

(f) The danger to the common adventure must not only be real. it must also be substantial. Again however, for policy reasons, Courts are fairly ready to ascribe substantial danger to any particular situation. ${ }^{72}$

(g) The sacrifice must be intentional, and losses arising through accident or intervention of superior forces, such as government orders, will not be made good in general average. Therefore, the sacrifice or expenditure must result from the deliberate exercise of reasoning power and discretion, usually on the part of the master, and be directed to preservation of the vessel and its cargo. ${ }^{73}$

(h) The general average act itself must usually be that of the master; the act of a stranger to the adventure will not qualify. Again, for policy reasons, the Courts will strain to find that an act done on the order of the owner or a government authority is the act of the master himself, on the fiction that the act was sanctioned, or at least acquiesced in, by the master, in the reasonable belief that it was necessary to preserve the maritime adventure. ${ }^{74}$

(i) There must be a common adventure, and while that sounds very simple. many difficulties may arise in practice. For example, to jettison cargo to enable the ship to take on board the passengers and crew of another vessel which is sinking or otherwise in distress would not be general average, for. although a sacrifice may be made, it is not made to avoid danger to the original maritime adventure. 75

(j) Where the fault or the act of one party to the adventure necessitates the sacrifice or expenditure, the fact of such fault does not preclude characterization as a general average act, but the party at fault is not entitled to contribution from any other party at whose instance such fault is actionable. ${ }^{76}$ Again, policy considerations arise related to avoiding circuity of action and to preventing a party legally at fault from recovering in general average for the consequences of his own actionable wrong. Examples of fault are unseaworthiness of the ship necessitating the sacrifice or expendi-

71. Lowndes \& Rudoif. supre ฉ. 63 \& 30: Monigowery \& Co. v. Ladematiy Mutesal Morne Insurance Co. Led. [1902] I K.B. 734 (C.A.).

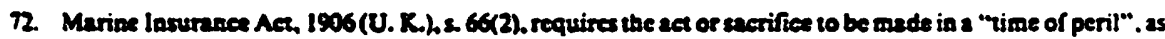

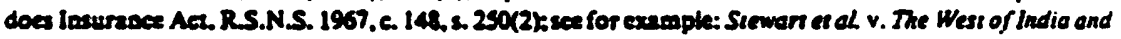

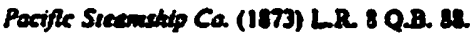

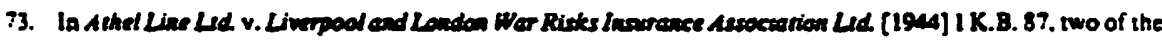
plaintifrs vesets. sailios in convoy froes Bermuda to the U.K. put beck to Beranuda in obedience to the order of the cosvoy conmodore, following Admirity instrvetions piven after as enemy attack on a grecediaf convoy. and the phintiff wes unable to recover the extra cost of fued and stores consumed in

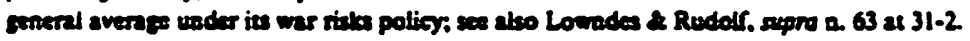

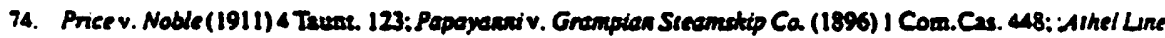
Led v. Liverpool and Loadon Wer Risks Innurence derociotion Led id

75. Lowndes \& Rudolf. suppe note 63. pp. 33-6.

76. See Goulandris Bothers Led v. B. Gathen A Soms LAd [1958] 1 Q.B. 74: Westem Canodo Sicemship Co Led. v. Canadian Commercial Corp. el d. [1960]S.C.R. 632: Canedien Trasepon Co. Ld v. Hunt. Leuchars. Hepburn LAd (1947) Ex. C.R. 83; Consolfdared Mbung a Smelting Co. of Ceneda Lid. v. Srroits Towing Led. [1972] 2 Lloyd's Rep. 497 (Ex. Ch); and also Federel Commerce \& Nowganon Co. Lid et el. v. EisenerzG.m.b.H. The "OAKAICL") (1974]S.C.R. 1225, showing that oven faull occurring after the peril may be of rebevance. 
ture in circumstances where the shipowner's liability was not excluded by the contract of carriage, or inherent vice of the cargo necessitating the general average act. The term "fault" in this context means actionable fault. If the fault is not actionable, because liability is exciuded by the contract of carriage or by statute, a party is not precluded from recovery in general average.

The charterparty usually refers to the York-Antwerp Rules, the most recent promulgation of which is the York-Antwerp Rules, 1974. ${ }^{77}$ Such Rules apply by contractual incorporation rather than by operation of law, and contractual acceptance of their application is found in virtually every charterparty or other contract of affreightment. The Rules do not form a complete code on the subject of general average. and they must be supplemented by the common law or by the statutory law applicable to the contract, or by the rules of practice of average adjusters, or by the custom at the port or place of adjustment.

Where general average acts or expenditures occur, professional average adjusters will determine the allowable expenditures and contributing values of the various interests, and will determine the amount or amounts to be made good in general average by one party to another. Canadian cases on the subject are rare. 78

\section{PAYMENT OF HIRE}

Hire is the consideration payable by the charterer to the owner for the provision of the ship and services specifed under the charter, and continuity of receipt of hire is obviously of significant importance to the owner. The amount of hire is normally a stipulated amount daily, based on a 24-hour day, seven days per week. Hire payment provisions in charterparties relating to com-

7. The Rules are reproduced in Lowndes \& Rudol, supre n. 63 in Appezdix l. commencing at p. 432.

78. In addition to the three Canadien cases referred to in n. 76. Other Canadian authorities are:

(a) The Westem Assurance Co. v. The Ontario Coel Ca. of Toronto (1892) 21 S.C.R. 383 - Following strading of the carrytn sessel, the cargo owner could have salvaged its cargo relasively inexpensively. but was nor parmitted to do so by the veseel's hull uaderwrites who ches atrempted to salvage the ship and carpo at great expense. eveutually savias some care but losing the ship. The underwriters chen sought a

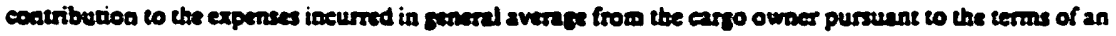
svernes boad provided by the carpo oweer, but the Suprewe Courr beld that the generd average burden to be throwa on the carpo ownet could wot execed the rensonable cose of aviag the carpo by ivelf:

(b) The Inomace Compenyy of Vornt Ameried v. Colonial Sreaneships Led. [1942] S.C.R. 357;

(c) Drew Brown LSd v. The "ORIEVT TRADER" [1974]S.C.R. 1286. A carto of tia slabs was shipped from Malayia to fhemileos under a contrace of carriese whieb incorporated the law of the United Seates. During diecharge in Toronio. a fire seared in other arpo rewulaias in serious carpo damage and loss of the ship. The owness of the tin sued for their loss and the shipowner counterelaimed for seneral average. The United States hed a Fire Shatute which exeluded a stipownes's tiability for fire damege undess enused by design or aeglect of the owner. The Court was divided. bet by a majority, beld the stripowner entitled to recover in general averafe from the carpo owner. as the shipowner's faule (if any) was nor actionible under the proper hw of the contract. Although there is a fire exception in the Carriage of Goods by Water Act. supre n. 3.

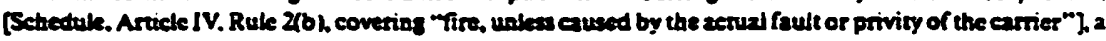
shipower will not be able to rely on the exeoption if be has failed in his obligacion to exercise due diligence in respect of seaworthiness (Mexine Foonmeor Co. Lid v. Canadien Govemment Merchent Marine Lsd [1959] A.C. 589 (R.C.)):

Canada does sot have a fire statute (surch as containad in the U. K. Merchant Shipping Act. 1894, s. 502 or as in the United States), so ultimate liabilities under Cansdiun Inw. inctuding liabilities to contribute in genera! sverage. may be quite different than if determined under the Entlisth or Ameriean law. (Sere, for example, Domineon Gless Co. Led v. The "ANGLO INDIAN" [19MA] S.C.R. AO9]. 
mercial vessels are carefully drafted and provide the charterer little, if any, latitude. Charters often stipulate that hire is payable in advance, at a time and in a manner set forth in the charterparty, failing which the owners may withdraw the vessel from the service of the charterer, without prejudice to any claim which the owner might otherwise have against the charterer. At common law, mere lateness in payment would not entitle the owner to withdraw the vessel, unless the circumstances of the charterer's failure showed an unwillingness or an inability to make payment, which amounted to repudiation of the charter. ${ }^{79}$ Thus, the contractual right to withdraw the vessel from service is of supreme importance to an owner.

The hire payment provisions in offshore supply vessel charters tend to give the charterer somewhat more latitude than would apply to charterers of commercial vessels generally, possibly because of the general reputation. solvency and bargaining power of such charterers, which are usually major oil companies or their affiliates.

While some offshore supply vessel charters provide that upon default of payment the owner shall have the right to withdraw the vessel immediately, others grant the owner an option to withdraw the vessel only upon notice to the charterer that the vessel will be withdrawn if hire is not paid before expiry of a period of grace. Such provisions are commonly referred to as "antitechnicality" clauses. In addition, some charters may provide for the payment of interest if payments due under the charter to the owner are outstanding for more than fifteen days beyond their due date.

A notice of withdrawal terminates the charterparty, and, to be effective, the notice of withdrawal must be given to the charterers and must state unequivocally that the owner intends to terminate. ${ }^{80}$ Temporary withdrawal of the vessel for nonpayment of hire is a right which exists only if it is specifically conferred on the owner under the terms of the time charter. ${ }^{31}$

In the reported cases, the failure to make a hire payment when due has frequently arisen through trivial mistake, possibly by the charterer's bank, but the owner has been held to be entitled to exereise the contractual right of withdrawal of the vessel nonetheless. Many judges have likened the withdrawal provision to forfeiture, and, until recently, it was an unresolved issue whether equitable relief from forfeiture applied in such a situation. In The LACONIA, ${ }^{82}$ Lord Salmon, in obiter dictum, expressed the opinion that the doctrine of equitable relief against forfeiture, would very rarely, if at all, be available in relation to a charterparty. However, he indicated that he could conceive of circumstances in which failure to make punctual payment might be due to pure accident and might occasion no real detriment to the owners, whereas withdrawal might cause extremely heavy losses to the charterers in circumstances where reasonable commercial people might think it unconscionable for the owners to take advantage of the failure, and that, in such circumstances, equitable relief from forfeiture might be available.

79. Wiford. Coghlin. Healy a Kimball. Time Charters (2ad ad. 1982). p. 156.

80. Aegnousstots Shipping Corporarion of Monrovia v. A/S Xristien Jebsens Rederi of Bergen The "AEGNOUSSIOTIS") [1977] I Lloyd's Rep. 263.

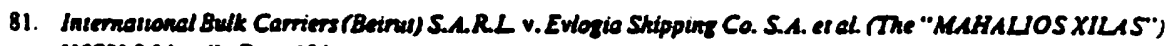
[1978] 2 Lloyd's Rep. 186.

82. (1977) I Lloyd's Rep. 315 a 322 (H.L.). 
On June 30. 1983. the House of Lords rejected the argument that the equitable relief principle could apply to time charters. ${ }^{83}$ In giving the decision. the House of Lords indicated that their observations were directed exclusively to time charters that were not by demise, and that identical considerations would not be applicable to bareboat charters.

The right of withdrawal may be waived by the owner's acceptance of a late payment before withdrawal of the vessel, but such accepiance of a late payment will not necessarily be implied merely because funds have been received by the owner's bank and the bank has started internal processing. ${ }^{84}$ Furthermore. acceptance of a timely, although insufficient, payment will not constitute a waiver of the shipowner's right of withdrawal, and the shipowner will have a reasonable time to review the charterer's deductions before giving notice of withdrawal. Such notice must be exercised within a reasonable time, otherwise it may be considered to have been waived. 85 The owners will be permitted a reasonable time to make inquiries through their banks to determine whether or not the payment has been made, and in doing so they will not waive the right to withdraw the vessel. ${ }^{86}$

As noted above, some charters provide the owner with an option to withdraw the vessel which can only be exercised after failure by the charterer to make payment when due, and only then upon notice being given to the charterer by the owner. Such anti-technicality clauses appear in many Canadian offshore supply vessel charters. In Afovos Shipping Co. S.A. v. Pagnan The $A F O V O S),{ }^{87}$ such a clause, rather inelegantly worded, provided that:

\footnotetext{
When hire is due and not recerved by the owners. before exercising the option of withdrawing the vesset from the etharterpary, will geve ctareers 48 bours notice. Saurdays. Sundays and holidays excluded and will nos wathdraw she vesset if the tire is paid wethin chase 48 hours.
}

The charterers had instructed their bank in Italy to remit funds by telex to the owners' bank in London, but due to a mistake in the telex directory, the telex went to a third party rather than to the London bank, and the mistake was not discovered for some days. On the due date, the owners advised the charterers that if the hire due on that day was not received, the vessel would be withdrawn from their service. Four days later, the owners withdrew the vessel for failure to pay hire. The House of Lords held that the 48 hours' notice stipulated in the anti-technicality clause could not validly be given until after midnight on the day when hire was due, and since the notice was given earlier, it was not valid. From this case, it would appear that the Courts will not grant equitable relief against forfeiture if the parties have agreed upon their own method of resolving such problems through incorporation of an anti-technicality clause.

83. Scandineveen Treding Tenker Co. A.B. v. Fole Petrolere Eenatoriana The "SCAPTRADE") (1983] LM.L.N. $\%$.

84. The "LACONIA". supre a. 82

85. Id

86. The "BALDER LONDON [1980]2 Lloyd's Rep. 489 - Norwegian Owners inquired through their London

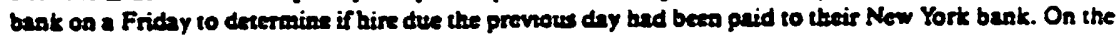
followis Monday. the London bank confiraned that the funds thad not beea recrived in New Yort. and the owner thereopon gave aesice of withdrawn. The Court did sor concider the tione taken for inquiry by the owner to be unreasonable, and the notiee of withdrawt was effectiver ses also: The "SCAPTRADE" [1981] 2 Lloyd's Rep. 425.

87. [1983] | W.L.R. 19S (H.L.). 


\section{OFF-HIRE}

Since no charterer wishes to make hire payments for periods when the chartered vessel is incapable of performing obligations contemplated by the charterparty, all time charters contain off-h:re provisions. ${ }^{88}$ The topic can be addressed only in the most general way, for the off-hire clauses vary considerably in their terms. Ordinarily, the off-hire clause will provide that in the event of any detention ${ }^{89}$ or loss of time due to deficiency of men or stores. breakdown of or damage to hull, machinery or equipment, drydocking, grounding, fumigation, quarantine. breach of orders or neglect of duty on the part of the master, officers or crew, fires, collision, or any cause rendering the vessel inefficient or unable to perform, and if such detention or loss of time shall continue for a specified period, then the vessel will go off-hire until it is again in an efficient state to resume the service.

Other circumstances may also lead to the vessel being placed off-hire, including detention through legal process, such as arrest, or detention by order of government authorities or requisition, or, of course, loss of the vessel itself. The purpose of off-hire clauses is to balance the interests of the two parties in such a way that the charterer only pays for what it gets.

There are times when a vessel may suffer from some breakdown or inefficiency which does not affect its full operation, but affects part of the service to be provided. It is a matter for determination in each case whether such a deficiency falls within the off-hire clause. Many times, the vessel is able to fulfill most of its functions, and the defect itself may not cause any loss of time which would result in the vessel being off-hire during that period.

The off-hire provisions in Canadian offshore supply vessel charters generally do not allow the owner much latitude. Obviously, the charterer is interested in having the vessel at its disposal continuousiy during the charter period, and extended periods of downtime may seriously prejudice the charterer's other activities and obligations. Therefore, it is not uncommon for the off-hire provisions to include a right of termination if off-hire exceeds a stipulated amount of time. In addition, charters usually contain specific provisions obliging the owner to have the vessel drydocked and to have routine maintenance performed. A vessel would ordinarily be off-hire for the purpose of drydocking, but on hire during regular maintenance, unless the maintenance periods exceed the specified time limit.

\section{MISCELLANEOUS COMMENTS}

Most offshore supply vessel charters contain a 'choice of laws' clause which often refers to the laws of a particular province. It is preferable to refer to the

88. The zencral rale is that a ship on time chaner is contiauously on bire unleas the charterer is able to brng iuself cleatly within the terms of any off-hire provisions - Mareva Novigotion Co. Lid. v. Cenena Armedore SA. The "MAREVA A.S.") [1977] I Lloyd's Rep. 368. at p. 381.

89. The word "detention" is urually incorporated in the off-hire clause, but its meaning is not elear. It may include deteation by judicial process. arrest or seizure. Sometimes the words are "detertion by average" (which refer simply to damaee). In The "MAREVA A.S.". sepra. Ker,, J., considered the word to refer to more than mere delay, and theught it to bear some specific and additional meaning. and that it was intended to refer to a physiel and peopraphieal constratut upon movement of the vesued in relation to her service under the charter. He found support for his remarks in the judgment of Devlin. J.. in Royal Greek Government v. Minister of Trenspors (1949) 83 LL.L.Rep. 238, at p. 239. 
Canadian maritime law and the laws of the favoured province because, as discussed above, maritime law and federal statutes will apply in many circumstances.

Some charterparties also provide that the parties agree to submit to the jurisdiction of the courts of a particular province, and that disputes arising out of the charter will be determined only by those Courts. ${ }^{90}$ Under such an exclusive jurisdiction clause, a charterer may waive any rights that it would otherwise have to institute an action in rem in the Federal Court of Canada and to obtain security for its claim by arrest of the vessel in that action.

Finally, the possibility of submission to arbitration deserves some consideration. In the commercial shipping world, the vast majority of charterparty disputes are resolved through the arbitration process. When such disputes, particularly those that are technical in nature, are submitted to experienced. skilled and knowledgeable arbitrators, resolution will often come more quickly and economically than through resort to the judicial process.

\section{APPENDIX A}

\section{UNITED KINGDOM STANDARD CONDITIONS FOR TOWAGE AND OTHER SERVICES (REVISED 1974)}

1.(a) The agreement between the Tugowner and the Hirer is and shall at all times be subject to and include each and all of the conditions hereinafter set out.

(b) For the purpose of these conditions:

(i) "towing" is any operation in connection with the holding, pushing, pulling, moving, escorting or guiding of the Hirer's vessel, and the expressions "to tow", "being towed" and "towage" shall be defined likewise.

(ii) "vessel" shall include any vessel, craft or object of whatsoever nature (whether or not coming within the usual meaning of the word "vessel") which the Tugowner agrees to tow or to which the Tugowner agrees at the request, express or implied, of the Hirer, to render any service of whatsoever nature other than towing.

(iii) "tender" shall include any vessel, craft or object of whatsoever nature which is not a tug but which is provided by the Tugowner for the performance of any towage or other service.

(iv) The expression "whilst towing" shall cover the period commencing when the tug or tender is in a position to receive orders direct from the Hirer's vessel to commence pushing, holding, moving, escorting, or guiding the vessel or to pick up ropes or lines, or when the tow rope has been passed

90. See generally. Roberson. Juriedietion Clouses and The Caredien Confliet of Lows (1982), 20 Alta. Law Rev. 296. 
to or by the tug or tender, whichever is the sooner, and ending when the final orders from the Hirer's vessel to cease pushing, holding, moving, escorting or guiding the vessel or to cast off ropes or lines has been carried out, or the tow rope has been finally slipped, whichever is the later, and the tug or tender is safely clear of the vessel.

(v) Any service of whatsoever nature to be performed by the Tugowner other than towing shall be deemed to cover the period commencing when the tug or tender is placed physically at the disposal of the Hirer at the place designated by the Hirer, or, if such be at a vessel, when the tug or tender is in a position to receive and forthwith carry out orders to come alongside and shall continue until the employment for which the tug or tender has been engaged is ended. If the service is to be ended at or off a vessel the period of service shall end when the tug or tender is safely clear of the vessel or, if it is to be ended elsewhere, then when any persons, baggage, goods, mails, specie, ship or engine parts or gear or articles of whatsoever description have been landed or discharged from the tug or tender and/or the service for which the tug or tender has been required is ended.

(vi) The word "tug" shall include "tugs", the word "tender" shall include "tenders", the word "vessel" shall include "vessels", the word "Tugowner" shall include "Tugowners", and the word "Hirer" shall include "Hirers".

(vii) The expression "Tugowner" shall include any person or body (other than the Hirer or the owner of the vessel on whose behalf the Hirer contracts as provided in Clause 2 hereof) who is a party to this agreement whether or not he in fact owns any tug or tender, and the expression "other Tugowner" contained in Clause 5 hereof shall be construed likewise.

2. If at the time of making this agreement or of performing the towage or of rendering any service other than towing at the request, express or implied, of the Hirer, the Hirer is not the owner of the vessel referred to herein as "the Hirer's vessel", the Hirer expressly represents that he is authorized to make and does make this agreement for and on behalf of the owner of the said vessel subject to each and all of these conditions and agrees that both the Hirer and the Owner are bound jointly and severally by these conditions.

3. Whilst towing or whilst at the request, express or implied, of the Hirer, rendering any service other than towing, the master and crew of the tug or tender shall be deemed to be the servants of the Hirer and under the control of the Hirer and/or his servants and/or his agents, and anyone on board the Hirer's vessel who may be employed and/or paid by the Tugowner shall likewise be deemed to be the servant of the Hirer and the Hirer shall accordingly be vicariously liable for any act or omission by any such person so deemed to be the servant of the Hirer.

4. Whilst towing, or whilst at the request, either express or implied of the Hirer, rendering any.service of whatsoever nature other than towing:

(a) The Tugowner shall not be responsible for or be liable 
(i) for damage of any description done by or to the tug or tender, or done by or to the Hirer's vessel or done by or to any cargo or other thing on board or being loaded on board or intended to be loaded on board the Hirer's vessel or the tug or tender or by or to any other object or property:

or

(ii) for loss of the tug or tender or the Hirer's vessel or of any cargo or other thing on board or being loaded on board or intended to be loaded on board the Hirer's vessel or the tug or tender or any other object or property;

or

(iii) for any personal injury or loss of life howsoever and wheresoever caused including personal injury or loss of life of the master and/or crew of and/or any person on board the tug or tender;

or

(iv) for any claim by a person not a party to this agreement for loss or damage of any description whatsoever,

arising from any cause, including (without prejudice to the generality of the foregoing) negligence at any time of the Tugowner's servants or agents, unseaworthiness, unfitness or breakdown of the tug or tender, its machinery, boilers, towing gear, equipment, lines, ropes or hawsers, lack of fuel, stores, speed or otherwise, and

(b) The Hirer shall be responsible for, pay for and indemnify the Tugowner against and in respect of any loss or damage and any claims of whatsoever nature or howsoever arising or caused whether covered by the provisions of Clause 4 (a) hereof or not (including any arising from or caused by the negligence of the Tugowner or his servants or agents) including the loss of or damage to the tug or tender, provided that the Hirer shall not be liable to the Tugowner for or in respect of loss, damage or claims which the Hirer proves (the burden of proof being on the Hirer) to have been solely caused by the failure of the Tugowner, and due to the actual fault or privity of the Tugowner, to make his tug or tender seaworthy for the towage or service other than towage.

Provided however, notwithstanding anything hereinbefore contained, the Tugowner shall under no circumstances be responsible for or be liable for any loss or damage caused or contributed to, by or arising out of any delay or detention of the Hirer's vessel or of the cargo on board or being loaded on board or intended to be loaded on board the Hirer's vessel or of any other object or property or of any person, or any consequences thereof, whether or not the same shall be caused or arise whilst towing or whilst at the request, either express or implied of the Hirer, rendering any service of whatsoever nature other than towing or at any other time whether before during or after the making of this agreement. 
5. The Tugowner shall at any time be entitled to substitute one or more tugs or tenders for any other tug or tender or tugs or tenders. The Tugowner shall at any time (whether before or after the making of this agreement between him and the Hirer) be entitled to contract with any other Tugowner (hereinafter referred to as "the other Tugowner") to hire the other Tugowner's tug or tender and in any such event it is hereby agreed that the Tugowner is acting (or is deemed to have acted) as the agent for the Hirer, notwithstanding that the Tugowner may in addition, if authorized whether expressly or impliedly by or on behalf of the other Tugowner, act as agent for the other Tugowner at any time and for any purpose including the making of any agreement with the Hirer. In any event should the Tugowner as agent for the Hirer contract with the other Tugowner for any purpose as aforesaid it is hereby agreed that such contract is and shall at all times be subject to the provisions of these conditions so that the other Tugowner is bound by the same and may as a principal sue the Hirer thereon and shall have the full benefit of these conditions in every respect expressed or implied therein.

6. Nothing contained in these conditions shall limit. prejudice or preclude in any way any legal rights which the Tugowner may have against the Hirer including, but not limited to, any rights which the Tugowner or his servants or agents may have to claim salvage remuneration or special compensation for any extraordinary services rendered to vessels or anything aboard the vesseis by any tug or tender. Furthermore, nothing contained in these conditions shall limit, prejudice or preclude in any way any right which the Tugowner may have to limit his liability.

7. The Tugowner will not in any event be responsible or liable for the consequences of war, riots, civil commotions, acts of terrorism or sabotage, strikes, lockouts, disputes, stoppages or labour disturbances (whether be be a party thereto or not) or anything done in contemplation or furtherance thereof or delays of any description, howsoever caused or arising, including by the negligence of the Tugowner or his servants or agents.

8. The Hirer of the tug or tender engaged subject to these conditions undertakes not to take or cause to be taken any proceedings against any servant or agent of the Tugowner or other Tugowner whether or not the tug or tender be substituted or hired or the contract or any part thereof has been sublet to the owner of the tug or tender, in respect of any negligence or breach of duty or other wrongful act on the part of such servant or agent which, but for this present provision, it would be competent for the Hirer so to do and the owners of such tug or tender shall hold this undertaking for the benefit of their servants and agents.

\section{APPENDIX B}

\section{EASTERN CANADIAN TUG OWNERS' LIMITED}

\section{STANDARD TOWING CONDITIONS}

1. The Tug Company will not be responsible for any delay in supplying tug service arising from any cause whatsoever or for any loss, damages or injuries 
which may be sustained in consequence thereof by the owners, charterers or operators of any vessel or craft or by any other person or persons interested therein.

2. Tug services will be supplied upon the condition that all towing, moving, shifting, docking, undocking or other handling of a vessel or craft of any character by a tug or tugs owned or employed by the Tug Company is done at the sole risk of such vessel or craft and of the owners, charterers or operators thereof, and that the Master and crew of such tug or tugs used in the said services become the servants of and identified with such vessel or craft and their owners, and that the Tug Company undertakes only to provide motive power.

3. The Tug Company will not be responsible for the acts, defaults, negligence, gross or otherwise, of the Master or crew of such tug or tugs, or any of their servants or agents or else whatsoever, nor for any damages, injuries, losses, delays, costs, expenses, infringement of rights from whatsoever cause arising, including unseaworthiness of the tug or tugs used in the said services, provided due diligence has been exercised by the Tug Company to make the tug or tugs seaworthy, that may occur either to such vessel or craft, or property or persons on board thereof, or to any other ship or vessel or property of any kind whether fixed or movable, and the Tug Company as well as the Master of the tug or tugs engaged in such services and their crew shall be held harmiess and indemnified by the Hirer against all such damages, injuries, losses, delays, costs, expenses and infringement of rights, and against all claims in respect thereof.

4. Such exemption from liability shall apply regardless of whether such vessel or craft assists in the services with its own steam or power or in any other way, and irrespective of whether any employee of the Tug Company or the Master or any of the crew of such tug or tugs is at the time of said services on board of such vessel or craft, or in command thereof.

5. The foregoing conditions shall apply to any damages, injuries, loss, costs, expenses and infringement of rights from whatsoever cause arising including unseaworthiness that may occur to the vessel or craft requiring the tug or tugs or to any other vessel or craft, or to any person or property on board thereof, or to any other property whether fixed or movable, while such tug or tugs is or are in attendance upon or fast to or engaged in any manoeuvre for the purpose of making fast to or disengaging from or proceeding clear from the vessel or craft requiring the tug or tugs, provided however that the said conditions shall not apply to loss of or damage to the tug or tugs or to property on board the tug or tugs or to damages for personal injuries to or loss of life of members of the crews of the tug or tugs or persons on board thereof, unless such loss or damage or such damages for personal injuries or loss of life shall have been caused or contributed to by the fault or negligence of the vessel or craft requiring the tug or tugs. 